\begin{tabular}{cc|c}
\hline Tar. Bil. Der. & Tarm Bilimleri Dergisi & Journal of Agricultural Sciences \\
& $\begin{array}{c}\text { Dergi web sayfası: } \\
\text { www.agri.ankara.edu.tr/dergi }\end{array}$ & Journal homepage: \\
& www.agri.ankara.edu.tr/journal
\end{tabular}

\title{
Effects of Biofloc Technology (BFT) on Growth of Speckled Shrimp (Metapenaeus monoceros)
}

\author{
Dogukan KAYA ${ }^{\mathrm{a}}$, M. Ayce GENC ${ }^{\mathrm{b}}$, Mevlut AKTAS ${ }^{\mathrm{b}}$, O. Tufan EROLDOGAN ${ }^{\mathrm{c}}$, Farah G. AYDIN ${ }^{\mathrm{d}}$, \\ Ercument GENC ${ }^{\text {a }}$ \\ a Ankara University, Faculty of Agriculture, Department of Fisheries and Aquaculture Engineering, 06110, Diskapi, Ankara, TURKEY \\ ${ }^{b}$ Iskenderun Technical University, Marine Science and Technology Faculty, Department of Aquaculture, 31200, Iskenderun, Hatay, TURKEY \\ ${ }^{c}$ Çukurova University, Faculty of Fisheries, Department of Aquaculture, 01330, Adana, TURKEY \\ 'Ankara University, Faculty of Veterinary Medicine, Department of Pharmacology and Toxicology, 06110, Diskapi, Ankara, TURKEY
}

\section{ARTICLE INFO}

Research Article

Corresponding Author: Dogukan KAYA, E-mail: dogukankaya@ankara.edu.tr, Tel: +90 (312) 5961074

Received: 09 July 2018, Received in Revised Form: 09 September 2018, Accepted: 11 October 2018

\begin{abstract}
The effects of biofloc technology (BFT) on growth and hepatopancreas histology of speckled shrimp Metapenaeus monoceros (initial weight: $8.32 \pm 0.69 \mathrm{~g}$ ) were investigated for 30 days. The trial was conducted in fiberglass tanks (45 L) with biofloc (zero-water exchange) and without biofloc (water exchange $50 \%$ day $^{-1}$ ). Different carbon sources (corn starch: CS and glycerine: G) and mannan oligosaccharides (MOS) supplementation (with and without BFT) were tested in triplicate groups. At the end of the experiment, better growth performances, feed conversion ratio, and specific growth rates were detected in shrimps reared in $\mathrm{BFT}(\mathrm{CS}, \mathrm{G}, \mathrm{CS}+\mathrm{MOS}, \mathrm{G}+\mathrm{MOS})$ groups. Measured water quality parameters (dissolved oxygen, $\mathrm{pH}$, temperature, salinity, ammonium- $\mathrm{NH}_{4}$, and nitrate- $\mathrm{NO}_{3}$ ) did not differ between $\mathrm{BFT}$ and control groups. The total number of bacteria count of shrimp reared in the biofloc groups were higher $\left(4.9 \times 10^{-6} \pm 8.5 \times 10^{-4} \mathrm{CFU}\right.$ $\left.\mathrm{mL}^{-1}\right)$ than that of in the without biofloc $\left(3.7 \times 10^{-6} \pm 5.4 \times 10^{-4} \mathrm{CFU} \mathrm{mL} \mathrm{mL}^{-1}\right)$ groups. In this study BFT had no negative effects on hepatopancreatic tissue by histological assessment. It is suggested that corn starch as a carbon source in BFT with 3 $\mathrm{g} \mathrm{kg}^{-1}$ MOS supplementation could be applied as healthy growth enhancer in speckled shrimp culture.

Keywords: Corn starch; Glycerol; Growth; Histology; Mannan oligosaccharides; Metapenaeus monoceros
\end{abstract}

(C) Ankara Üniversitesi Ziraat Fakültesi

\section{Introduction}

Aquaculture plays a crucial role for supporting the world's needs of protein (Jackson 2007; Kuhn et al 2010). According to FAO and World Bank 2030-2050 projections the production capacity of aquaculture should be doubled because of the population increases and global warming. The report also proposes that agriculture will be practiced in marine environment. In order to achieve this successful and secure food production, the industry will obviously need to develop new technologies that will increase sustainable economic profitability and environmental concerns. Intensive aquaculture applications work with great amounts of clean water exchange ratios to sustain acceptable water quality (Wang 1990; Hopkins 
et al 1993; Moss et al 1999; Mishra et al 2008). However, due to environmental concerns like conservation of water sources, the requirement for more ecologically sound management and aquaculture practices is also growing steadily (Emerenciano et al 2012).

It is known that microorganisms have an important influence on nutrition cycle, water quality, and nourishment of cultured species (Emerenciano et al 2011). Biofloc technology is a technique utilized to increase water quality and create extra protein resources by adding an external carbon source into environmentally friendly aquaculture systems. The sustainable and recyclable food production approach based on such a system is dependent on the growth of microorganisms. Biofloc technology today has been implemented with minimum or zero water exchange in culture systems. Moreover, it is possible to reduce feed consumption by recycling all the waste for the edible food sources by BFT for cultured species (Kaya \& Genc 2018).

Studies investigating alternative/new species for aquaculture are vitally important to gain insight regarding market diversification and minimization of food shortage. Speckled shrimp, Metapenaeus monoceros, is the one of highly demanded penaeid shrimp in fish market of Mediterranean and IndoPacific region and is considered as an alternative species in aquaculture. The main objective of the current study was to determine the growth parameters, survival, and hepatopancreas histology of speckled shrimp with BFT (in zero water exchange) and without BFT application $\left(50 \%\right.$ day $^{-1}$ water exchange).

\section{Material and Methods}

\subsection{Experimental design and culture conditions}

The study was conducted at the Fisheries Research Unit (Faculty of Agriculture, Ankara University), Ankara, Turkey. The trial was conducted in fiberglass tanks (45 L) with biofloc (zero-water exchange) and without biofloc (water exchange $50 \%$ day $^{-1}$ ).
Shrimps used in the study were obtained from the Faculty of Marine Sciences and Technology of Iskenderun University and transported to the Ankara University.

Effects of biofloc treated with two different carbon sources (corn starch: CS and glycerine: G) and mannan oligosaccharide (MOS) as a prebiotic on growth of speckled shrimp were investigated. In the experiment, 90 shrimps $(8.32 \pm 0.69 \mathrm{~g})$ were used in four different biofloc groups (CS, $\mathrm{G}, \mathrm{CS}+\mathrm{MOS}, \mathrm{G}+\mathrm{MOS}$ ) and two groups without biofloc (MOS and Control) for 30 days. Each treatment was randomized with three replicates (5 shrimps/tank). Each biofloc was produced with different carbon sources (by starting before the 15 days of experiment and maintained with daily carbon addition, at 28.82-29.33 ppt salinity and $25.10-25.45{ }^{\circ} \mathrm{C}$ water temperature). Biofloc volume was controlled with imhoff to ensure that it remains at the level of $10-20 \mathrm{~mL} \mathrm{~L}^{-1}$ in biofloc groups. Shrimp were fed with $45 \%$ crude protein and $20 \%$ lipid marine fish commercial diet (Sibal LTD. Sinop, Turkey) at $3 \%$ of the estimated biomass (three times a day; 08.00, 13.00, 18.00) throughout the experiment. In the trial, a 12-h photoperiod was sustained by using fluorescent lighting. Corn starch and glycerine were added daily after feeding to maintain $\mathrm{C}: \mathrm{N}$ as 15 during the study to ensure heterotrophic bacterial growth.

\subsection{Water quality parameters}

Throughout the experimental period, $\mathrm{pH}$, temperature, salinity, and dissolved oxygen were measured daily using a multi-parameter instrument (YSI ${ }^{\circledR}$ 556, YSI Inc., Yellow Springs, OH, USA) at 08:30 hours in all tanks. Ammonium $\left(\mathrm{NH}_{4}\right)$ and nitrate $\left(\mathrm{NO}_{3}\right)$ were monitored once a week according to standard methods (APHA 1998).

\subsection{Growth parameters}

At the end of the study, the final weight, daily weight gain, feed conversion ratio (FCR), specific growth rate (SGR), and survival rate of six treatments were calculated as indicated below. 
Weight gain $(\mathrm{g} /$ shrimp $)=$ Final weight $(\mathrm{g})$ - Initial weight $(\mathrm{g})$

Feed conversion ratio $(\mathrm{FCR})=$ Total feed given $(\mathrm{g}) /$ Weight gain $(\mathrm{g})$

Specific growth rate $(\mathrm{SGR} ; \% /$ day $)=((\ln ($ Final weight $)-\ln ($ Initial weight $)) /$ days $) \times 100$

Survival rate $(\%)=($ Final number of shrimp $) /($ Initial number of shrimp $) \times 100$

\subsection{Histology}

Three shrimp samples from each triplicate group were anaesthetized with $5 \mathrm{mg} \mathrm{L}^{-1}$ quinaldine (Sigma Chemical Company, St. Louis, Missouri, USA) (Genc et al 2007), the carapax were opened, and hepatopancreas tissue were removed by dorsoventral incision. The hepatopancreas samples were fixed for $24 \mathrm{~h}$ in $10 \%$ buffered formaline solution. After dehydration by passing tissues through a series of ethanol solutions (70, 85 and $98 \%)$ and clarification by two series of xylene, the samples were vacuum embedded in paraffin at $59 \pm 1{ }^{\circ} \mathrm{C}$. The microtome sections (4-5 $\mu \mathrm{m}$, Thermo Shandon, Germany) were stained for morphological purposes with haematoxylin and eosin ( $\mathrm{H} \& \mathrm{E})$ and then were analysed on microphotographs (Leica CM40) (Roberts \& Smail 2004).

\subsection{Total bacterial counts}

Water samples from the culture tanks were stored in sterile glass bottles $(50 \mathrm{~mL})$ and analysed for total heterotrophic bacteria (THB). The preparation of the sample dilutions and bacteriological assays of the water were conducted separately and their averages were computed using the method described by APHA (2005). Total viable bacterial count from tank water was determined by the spread-plate technique on Plate Count Agar (PCA) with $2 \% \mathrm{NaCl}$. In each sample, serial dilutions were prepared in macro dilution tubes with concentrations ranging between $10^{-1}$ to $10^{-8}$ and were incubated at $37{ }^{\circ} \mathrm{C}$ for 48 hours. After the incubation period, the colonies were counted by eye and $\mathrm{CFU}$ values $\left(\mathrm{CFU} \mathrm{mL} \mathrm{m}^{-1}\right)$ were calculated. Cultures containing less than 30 colonies and more than 300 colonies were not considered in the analyses.

The CFU mL $\mathrm{mL}^{-1}$ values were calculated using the formula;

\subsection{Statistical analysis}

Statistical analysis was performed using SPSS, IBM, Statistics 23.0 for Windows. Analysis of variance (ANOVA) was used on shrimp performance and water quality parameters data to analyse the effect of BFT. The $\alpha$ level of 5\% was used for all tests.

\section{Results and Discussion}

Water quality values are listed in Table 1 . There were significant differences $(\mathrm{P}<0.05)$ among groups with regards to dissolved oxygen and $\mathrm{pH}$ parameters. Levels of dissolved oxygen and $\mathrm{pH}$ ranged from 6.02 to $6.29 \mathrm{mg} \mathrm{L}^{-1}$ and 7.73 to 7.96 , respectively. The concentrations of ammonium $\left(\mathrm{NH}_{4}\right)$ and nitrate $\left(\mathrm{NO}_{3}\right)$ were found similar for all groups $(\mathrm{P}>0.05)$. The total number of bacteria count of shrimp reared in the biofloc groups were higher $\left(4.9 \times 10^{-6} \pm 8.5 \times 10^{-4}\right.$ $\left.\mathrm{CFU} \mathrm{mL} \mathrm{m}^{-1}\right)$ than that of in the no-biofloc $\left(3.7 \times 10^{-6}\right.$ $\left.\pm 5.4 \times 10^{-4} \mathrm{CFU} \mathrm{mL}^{-1}\right)$ groups $(\mathrm{P}<0.05)$ (Table 2$)$.

Shrimp growth performance is presented in Table 3. Final weights of shrimp reared in CS+MOS group were significantly higher $(\mathrm{P}<0.05)$ than that of shrimp reared in MOS and $\mathrm{C}$ groups. There was no significant difference among the biofloc treated groups in terms of final weights $(\mathrm{P}>0.05)$. The highest weight gain $(\mathrm{g})$ was obtained in group $\mathrm{CS}+\mathrm{MOS}$ and the lowest value was observed in the control group $(\mathrm{P}<0.05)$. The best feed conversion ratio (FCR) of shrimp was observed in group $\mathrm{CS}+\mathrm{MOS}$ and the highest FCR was calculated from the control group $(\mathrm{P}<0.05)$. The specific growth rate $(\% /$ day) and survival rate $(\%)$ of shrimp were higher in the biofloc treatments compared to the MOS and $\mathrm{C}$, but no significant differences were detected among all groups $(\mathrm{P}>0.05)$.

$\mathrm{CFU} \mathrm{mL}-1=($ no. of colonies $\mathrm{x}$ dilution factor $) /$ volume of culture plate

Tarım Bilimleri Dergisi - Journal of Agricultural Sciences 25 (2019) 491-497 
Table 1- Water quality parameters of speckled shrimp culture environments

\begin{tabular}{|c|c|c|c|c|c|c|}
\hline \multicolumn{5}{|c|}{ Biofloc groups } & \multicolumn{2}{|c|}{ Without biofloc groups } \\
\hline $\begin{array}{l}\text { Water } \\
\text { parameters }\end{array}$ & CS & $G$ & $C S+M O S$ & $G+M O S$ & $M O S$ & Control \\
\hline $\mathrm{DO}\left(\mathrm{mg} \mathrm{L}^{-1}\right)$ & $6.29 \pm 0.42^{\mathrm{a}}$ & $6.06 \pm 0.26^{\mathrm{ab}}$ & $6.02 \pm 0.68^{b}$ & $6.07 \pm 0.35^{\mathrm{ab}}$ & $6.06 \pm 0.23^{\mathrm{ab}}$ & $6.15 \pm 0.41^{\mathrm{ab}}$ \\
\hline $\mathrm{pH}$ & $7.95 \pm 0.18^{\mathrm{b}}$ & $7.73 \pm 0.45^{\mathrm{a}}$ & $7.88 \pm 0.19^{\mathrm{b}}$ & $7.96 \pm 0.14^{\mathrm{b}}$ & $7.95 \pm 0.10^{\mathrm{b}}$ & $7.94 \pm 0.10^{\mathrm{b}}$ \\
\hline $\mathrm{T}\left({ }^{\circ} \mathrm{C}\right)$ & $25.15 \pm 0.50$ & $25.30 \pm 0.55$ & $25.10 \pm 0.70$ & $25.45 \pm 0.50$ & $25.20 \pm 0.64$ & $25.29 \pm 0.72$ \\
\hline Salinity ppt & $29.33 \pm 0.76$ & $29.07 \pm 0.87$ & $29.03 \pm 0.85$ & $28.93 \pm 0.90$ & $28.82 \pm 0.86$ & $29.13 \pm 1.22$ \\
\hline $\mathrm{NH}_{4}\left(\mathrm{mg} \mathrm{L}^{-1}\right)$ & $0.18 \pm 0.01$ & $0.23 \pm 0.05$ & $0.14 \pm 0.01$ & $0.15 \pm 0.01$ & $0.15 \pm 0.01$ & $0.14 \pm 0.01$ \\
\hline $\mathrm{NO}_{3}\left(\mathrm{mg} \mathrm{L}^{-1}\right)$ & $0.21 \pm 0.10$ & $0.21 \pm 0.10$ & $0.21 \pm 0.10$ & $0.25 \pm 0.09$ & $0.23 \pm 0.09$ & $0.25 \pm 0.09$ \\
\hline
\end{tabular}

CS, Corn starch; G, Glycerol; MOS, Mannan oligosaccharides. Different superscripts in the same line indicate significant differences $(\mathrm{P}<0.05)$

Table 2- Results of total aerobic bacteria counts

\begin{tabular}{lcccccc}
\hline \multicolumn{5}{c}{ Biofloc groups } & & Without Biofloc groups \\
\hline $\begin{array}{l}\text { Total aerobic } \\
\text { bacteria }\end{array}$ & $C S$ & $G$ & $C S+$ MOS & G+MOS & MOS & Control \\
\hline TBC CFU $\left(\mathrm{mL}^{-1}\right)$ & $4.8 \times 10^{-6} \pm$ & $4.8 \times 10^{-6} \pm$ & $5.0 \times 10^{6} \pm$ & $5.0 \times 10^{-6} \pm$ & $4.1 \times 10^{-5} \pm$ & $3.3 \times 10^{-5} \pm$ \\
& $5.8 \times 10^{-4 \mathrm{~b}}$ & $5.8 \times 10^{-4 \mathrm{~b}}$ & $5.8 \times 10^{-4 \mathrm{c}}$ & $5.8 \times 10^{-4 \mathrm{c}}$ & $3.3 \times 10^{-4 \mathrm{a}}$ & $1.5 \times 10^{-4 \mathrm{a}}$ \\
\hline Mean CFU $\left(\mathrm{mL}^{-1}\right)$ & & $4.9 \times 10^{-6} \pm 8.5 \times 10^{-4}$ & & $3.7 \times 10^{-6} \pm 5.4 \times 10^{-4}$ \\
\hline
\end{tabular}

CS, Corn starch; G, Glycerol; MOS, Mannan oligosaccharides. Different superscripts in the same line indicate significant differences $(\mathrm{P}<0.05)$

Table 3- Growth parameters

\begin{tabular}{lcccccc}
\hline \multicolumn{5}{c}{ Biofloc groups } \\
\hline $\begin{array}{l}\text { Growth } \\
\text { parameters }\end{array}$ & CS & $G$ & CS + MOS & $G+M O S$ & MOS & Control \\
\hline IW (g) & $8.33 \pm 0.69^{\mathrm{a}}$ & $8.30 \pm 0.79^{\mathrm{a}}$ & $8.36 \pm 0.83^{\mathrm{a}}$ & $8.36 \pm 0.81^{\mathrm{a}}$ & $8.32 \pm 0.74^{\mathrm{a}}$ & $8.35 \pm 0.75^{\mathrm{a}}$ \\
FW (g) & $10.99 \pm 0.9^{\mathrm{ab}}$ & $10.89 \pm 0.77^{\mathrm{ab}}$ & $11.51 \pm 0.75^{\mathrm{b}}$ & $10.93 \pm 0.93^{\mathrm{ab}}$ & $10.65 \pm 1.06^{\mathrm{a}}$ & $10.44 \pm 0.83^{\mathrm{a}}$ \\
WG (g) & $2.64 \pm 0.62^{\mathrm{ab}}$ & $2.63 \pm 0.32^{\mathrm{ab}}$ & $3.15 \pm 0.28^{\mathrm{b}}$ & $2.56 \pm 0.36^{\mathrm{ab}}$ & $2.36 \pm 0.69^{\mathrm{ab}}$ & $2.08 \pm 0.36^{\mathrm{a}}$ \\
FCR & $2.81 \pm 0.63^{\mathrm{ab}}$ & $2.89 \pm 0.32^{\mathrm{ab}}$ & $2.38 \pm 0.26^{\mathrm{a}}$ & $2.92 \pm 0.49^{\mathrm{ab}}$ & $3.24 \pm 0.90^{\mathrm{ab}}$ & $3.59 \pm 0.73^{\mathrm{b}}$ \\
SGR (\%/day) & $0.92 \pm 0.21^{\mathrm{a}}$ & $0.92 \pm 0.09^{\mathrm{a}}$ & $1.07 \pm 0.11^{\mathrm{a}}$ & $0.89 \pm 0.13^{\mathrm{a}}$ & $0.83 \pm 0.24^{\mathrm{a}}$ & $0.75 \pm 0.16^{\mathrm{a}}$ \\
SR (\%) & $93.33^{\mathrm{a}}$ & $86.67^{\mathrm{a}}$ & $93.33^{\mathrm{a}}$ & $93.33^{\mathrm{a}}$ & $86.67^{\mathrm{a}}$ & $86.67^{\mathrm{a}}$ \\
\hline
\end{tabular}

CS, Corn starch; G, Glycerol; MOS, Mannan oligosaccharides. Different superscripts in the same row indicate significant differences $(P<0.05)$ IW: Initial weight, FW: Final weight, WG: Weight gain, FCR: Feed conversion ratio, SGR: Specific growth rate, SR: Survival rate

Hepatopancreas morphology was normal and did not differ among the groups (Figure 1). Different cell types were recognized but the structures were normal.
There are limited studies on growth of speckled shrimp, M. monoceros. In this study, water quality parameters $(\mathrm{DO}, \mathrm{pH}$, temperature, and salinity) were measured in the recommended range of 

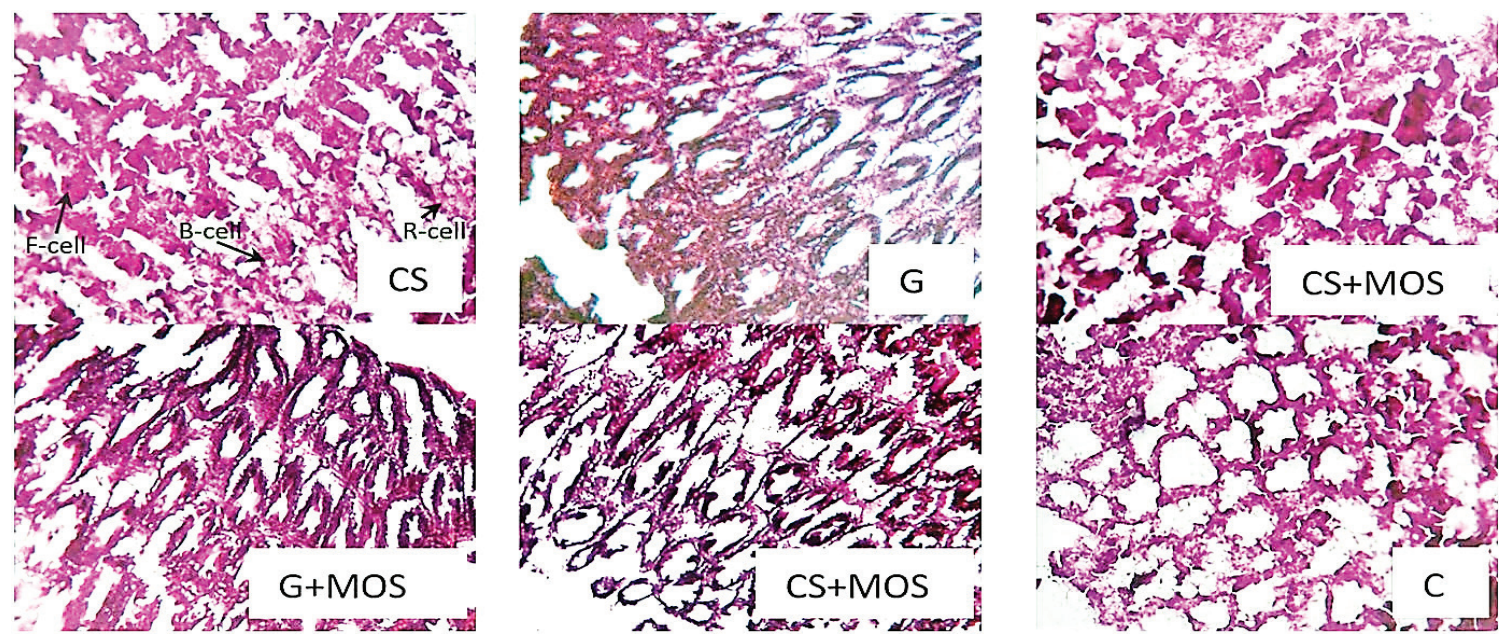

Figure 1- Speckled shrimp hepatopancreas tissue sections (10x, H \& E)

marine shrimp culture with BFT. Water quality parameters observed in the current study were found to be similar to the study by Rahman et al (2010) for speckled shrimp. In BFT, where water exchange is limited, the inhibition of accumulation of nitrogenous toxic compounds may be possible by maintaining high $\mathrm{C}: \mathrm{N}$ ratio and the consumption of ammonia by the microbial community (Avnimelech 1999; Kuhn et al 2010; Emerenciano et al 2012). In this study, ammonium and nitrate levels did not differ statistically between BFT and without BFT groups. Results reveal that the use of corn starch and glycerol as the carbon source and the maintenance of the optimum $\mathrm{C}: \mathrm{N}$ ratio can sustain the low level of toxic nitrogen compounds in the culture environment. The mean total number of bacteria counts in the BFT groups were observed in similar ranges compared to the ranges reported in previous study (4.23-4.55 $\left.\times 10^{-6} \mathrm{CFU} \mathrm{mL}^{-1}\right)$ by de Paiva Maia et al (2016). However, bacterial count ranges not only in BFT groups but also in without BFT groups of the present study were higher $\left(245.67 \times 10^{-8}\right.$ CFU $\mathrm{mL}^{-1}$ ) compared to the study by Anand et al (2014). This discrepancy may be explained by the low salinity (13.67-14.29 ppt) conditions used in the previously mentioned study.
Digestive glands consist of diverticula of the intestine and the main functions of the hepatopancreas are absorbing nutrients, storing lipids, and producing digestive enzymes (Johnson 1980; Genc et al 2007). According to the literature on physiology of digestion, absorption plays an important role in lipoprotein metabolism and could be used to monitor nutritional value of shrimp diets. In this study, the speckled shrimp reared with BFT and without BFT conditions fed on commercial marine fish diet with or without MOS supplementation showed similar and normal morphology.

It is argued that it can be possible to obtain better yield from a unit of area by using BFT in aquaculture. In our experiment, the growth parameters (the final weight, daily weight gain, feed conversion ratio, specific growth rate, and survival rate) were higher in BFT groups than the shrimp in the without BFT groups. The final weight of shrimp treated with CS + MOS was statistically higher than that of shrimp reared in the control group $(\mathrm{P}<0.05)$. These results revealed that BFT increased growth parameters in shrimp culture in parallel with previous studies (Krummenauer et al 2011; Emerenciano et al 2011; Xu \& Pan 2012; Emerenciano et al 2012; Kumar et al 2017; Lara et al 2017). 


\section{Conclusions}

Although previous studies focused on the effects of different carbon sources in BFT on growth parameters (Crab et al 2012; Emerenciano et al 2013), the current study investigated the effect of prebiotic supplementation with two different carbon sources. In conclusion, the combined use of corn starch and mannan oligosaccharide in biofloc technology could be considered as a productive application for shrimp culture. In addition, BFT application on speckled shrimp larvae is recommended for future studies. This study is the first record on speckled shrimp $M$. monoceros culture with BFT treatment.

\section{Acknowledgements}

The authors would like to thank to private fish food production company (Sibal LTD. Sinop, Turkey) for their support and also thanks to the anonymous referees for their constructive comments and contributions in the manuscript evaluation processes.

\section{References}

Anand P S S, Kohli M P S, Kumar S, Sundaray J K, Roy S D, Venkateshwarlu G, Sinha A \& Pailan G H (2014). Effect of dietary supplementation of biofloc on growth performance and digestive enzyme activities in Penaeus monodon. Aquaculture 418: 108-115

APHA (1998). Standard methods for the examination of the water and wastewater, $22^{\text {nd }}$ edn. American Public Health Association, Washington, DC

APHA (2005). Standard methods for the examination of water and wastewater, American Public Health Association, Washington DC

Avnimelech Y (1999). Carbon/nitrogen ratio as a control element in aquaculture systems. Aquaculture 176(34): 227-235

Crab R, Defoirdt T, Bossier P \& Verstraete W (2012). Biofloc technology in aquaculture: beneficial effects and future challenges. Aquaculture 356: 351-356

de Paiva Maia E, Alves Modesto G, Otavio Brito L, Olivera Galvez A \& Vasconcelos Gesteira T C (2016). Intensive culture system of Litopenaeus vannamei in commercial ponds with zero water exchange and addition of molasses and probiotics. Revista de Biología Marina y Oceanografía 51(1): 61-67
Emerenciano M, Ballester E L, Cavalli R O \& Wasielesky W (2011). Effect of biofloc technology (BFT) on the early postlarval stage of pink shrimp Farfantepenaeus paulensis: growth performance, floc composition and salinity stress tolerance. Aquaculture International 19(5): 891-901 http://dx.doi.org/10.1007/s10499-0109408-6

Emerenciano M, Ballester E L, Cavalli R O \& Wasielesky W (2012). Biofloc technology application as a food source in a limited water exchange nursery system for pink shrimp Farfantepenaeus brasiliensis (Latreille, 1817). Aquaculture Research 43(3): 447-457 http:// dx.doi.org/10.1111/j.1365-2109.2011.02848.x

Emerenciano M, Gaxiola G \& Cuzon G (2013). Biofloc technology (BFT): a review for aquaculture application and animal food industry. In: Matovic MD (Ed.) Biomass Now-Cultivation and Utilization, InTech, Queen's University, Belfast, Canada. pp. 301328 http://dx.doi.org/10.5772/53902

Genc M A, Aktas M, Genc E \& Yilmaz E (2007). Effects of dietary mannan oligosaccharide on growth, body composition and hepatopancreas histology of Penaeus semisulcatus (de Haan 1844). Aquaculture Nutrition 13(2): 156-161 http://dx.doi.org/10.1111/j.1365-2095. 2007.00469.x

Hopkins J S, Hamilton R D, Sandifer P A, Browdy C L \& Stokes A D (1993). Effect of water exchange rates on production, water quality, effluent characteristics and nitrogen budget in intensive shrimp ponds. Journal of the World Aquaculture Society 24: 304-320

Jackson A J (2007). Challenges and opportunities for the fishmeal and fish oil industry. Feed Technology Update, 2(1): 9

Johnson P T (1980). Histology of the Blue Crab, Callinectes sapidus: A model for the Decapoda. Praeger, New York

Kaya D \& Genc E (2018). Su ürünleri yetiştiriciliğinde biyoyumak teknolojisi. Su Urunleri Dergisi 35(2):219225 http://dx.doi.org/10.12714/egejfas.2018.35.2.16

Krummenauer D, Peixoto S, Cavalli R O, Poersch L H \& Wasielesky W (2011). Superintensive culture of white shrimp, Litopenaeus vannamei, in a biofloc technology system in southern Brazil at different stocking densities. Journal of the World Aquaculture Society 42(5): 726-733 http://dx.doi.org/10.1111/ j.1749-7345.2011.00507.x

Kuhn D D, Lawrence A L, Boardman G D, Patnaik S, Marsh L \& Flick Jr G J (2010). Evaluation of two types 
of bioflocs derived from biological treatment of fish effluent as feed ingredients for Pacific white shrimp, Litopenaeus vannamei. Aquaculture 303(1-4): 28-33 http://dx.doi.org/10.1016/j.aquaculture.2010.03.001

Kumar S, Anand P S S, De D, Deo A D, Ghoshal T K, Sundaray J K, Biswas G \& Lalitha N (2017). Effects of biofloc under different carbon sources and protein levels on water quality, growth performance and immune responses in black tiger shrimp Penaeus monodon (Fabricius, 1978). Aquaculture Research 48(3): 1168-1182 http://dx.doi.org/10.1111/are.12958

Lara G, Krummenauer D, Abreu P C, Poersch L H \& Wasielesky W (2017). The use of different aerators on Litopenaeus vannamei biofloc culture system: effects on water quality, shrimp growth and biofloc composition. Aquaculture International 25(1): 147162 http://dx.doi.org/10.1007/s10499-016-0019-8

Mishra J K, Samocha T M, Patnaik S, Speed M, Gandy R L \& Ali A M (2008). Performance of an intensive nursery system for the Pacific white shrimp, Litopenaeus vannamei, under limited discharge condition. Aquacultural Engineering 38(1): 2-15

Moss S M, Pruder G D \& Samocha T M (1999). Environmental management and control: controlled ecosystem and biosecure shrimp grow-out systems.
In: R A Bullis, G D Pruder (Eds.) Controlled and biosecure production systems, preliminary proceedings of a special integration of shrimp and chicken models. World Aquaculture Society Sydney, Australia, pp. 87-91

Rahman S H A, Razek F A A, Goda A M A-S, Ghobashy A F A, Taha S M \& Khafagy A R (2010). Partial substitution of dietary fish meal with soybean meal for speckled shrimp, Metapenaeus monoceros (Fabricius, 1798) (Decapoda: Penaeidae) juvenile. Aquaculture Research 41(9): 299-306 http://dx.doi.org/10.1111/ j.1365-2109.2010.02530.x

Roberts R J \& Smail D A (2004). Laboratory methods. In: R J Roberts, (Ed.), Fish Pathology, $3^{\text {rd }}$ edn. W.B. Saunders, London, pp. 380-412

Wang J K (1990). Managing shrimp pond water to reduce discharge problems. Aquaculture Engineering 9: 6173

Xu W J \& Pan L Q (2012). Effects of bioflocs on growth performance, digestive enzyme activity and body composition of juvenile Litopenaeus vannamei in zero-water exchange tanks manipulating $\mathrm{C} / \mathrm{N}$ ratio in feed. Aquaculture 356: 147-152 http://dx.doi. org/10.1016/j.aquaculture.2012.05.022 